\title{
Density of white-tailed deer in relation to vegetation in a landscape of northern Veracruz
}

\author{
Rosario del Ángel ${ }^{1}$ and Salvador Mandujano ${ }^{2 *}$ \\ ${ }^{1}$ Facultad de Ciencias Biológicas y Agropecuarias, Universidad Veracruzana, Campus Peñuela. Camino Peñuela-Amatlán CP \\ 94945, Amatlán de los Reyes. Veracruz, México. Email: aries 02329@hotmail.com \\ ${ }^{2}$ Red de Biología y Conservación de Vertebrados, Instituto de Ecología, A. C., Carretera antigua a Coatepec 351, El Haya CP. 91070 , \\ Xalapa. Veracruz, México. Email: salvador.mandujano@inecol.mx (SM) \\ * Autor de correspondencia
}

The white-tailed deer, Odocoileus virginianus, is poorly known in the state of Veracruz, Mexico. In this paper we report the relationships between deer population density and vegetation variables in a landscape in Tantoyuca, northern Veracruz. Pellet groups and vegetation were sampled across 40 strip transects $(500 \times 2 \mathrm{~m})$ in five locations from April to June 2014 . The relationships between deer density and vegetation variables were evaluated with hierarchical agglomerative clustering methods to group tree species per transect, as well as generalized linear models. Density (number of deers $/ \mathrm{km}^{2}$ ) was estimated using the semi-automated process PELLET, and was compared between locations, major vegetation types, and transect clusters. Deers were present in $98 \%$ of the transects sampled, with a mean density of $4.2 \pm 2.8$ deers $/ \mathrm{km}^{2}$. Higher densities were estimated in secondary vegetation and pasture-cropping sites. The 40 transects were grouped into four clusters according to the abundance of tree species. In addition, deer density varied between clusters. The density of the white-tailed deer was positively correlated with understory cover and negatively correlated with basal area. Deer density in Tantoyuca is within the range reported in other regions of the state of Veracruz. The use of generalized linear models enabled to predict the density of the white-tailed deer based on some vegetation variables. The localities studied differ in plant composition and structure, and the highest deer density was located in sites with a more diverse and dense plant composition and structure. It is suggested to undertake an in-depth investigation about the effect of landscape structural complexity and connectivity on this and other wildlife species.

El venado cola blanca Odocoileus virginianus ha sido poco estudiado en el estado de Veracruz, México. En el presente trabajo se estimó la densidad poblacional de esta especie y se analizó su relación con la vegetación en un paisaje transformado en cinco localidades en municipio de Tantoyuca en el norte del estado. En cada localidad se colocaron 8 transectos $(500 \times 2 \mathrm{~m})$ para el conteo del número de grupos fecales y la caracterización de la vegetación, y se muestrearon de abril a junio del 2014. Se emplearon análisis de agrupamiento jerárquicos de los transectos en función de similitud en la composición del estrato arbóreo, y modelos lineales generalizados para relacionar la densidad de venados con las variables vegetacionales. La densidad (venados $/ \mathrm{km}^{2}$ ) se estimó con el procedimiento semi-automatizado PELLET, y se comparó entre localidades, principales tipos de vegetación, y grupos de transectos. Los venados estuvieron presentes en el 98 \% de los transectos y se estimó la densidad promedio de $4.2 \pm 2.8$ venados $/ \mathrm{km}^{2}$. Las densidades más altas se estimaron en la vegetación secundaria con remanentes de selva baja y en las zonas de cultivos-pastizal. El área basal y la cobertura del sotobosque fueron las principales variables para predecir la densidad de este venado en la región de estudio. Los 40 transectos se clasificaron en 4 grupos de acuerdo a la dominancia de las especies arbóreas, y la densidad de venados difirió entre estos grupos. La densidad venados en Tantoyuca se encuentra dentro del rango reportado en otras regiones del estado de Veracruz. Empleando modelos lineales generalizados fue posible predecir la densidad de venado cola blanca en función de algunas variables vegetacionales. Las localidades estudiadas difieren en cuanto a la composición y estructura vegetal, y la mayor densidad de venados se localizó en los sitios con una composición y estructura vegetal más diversa y densa. Se sugiere profundizar en el estudio para conocer el efecto de la complejidad estructural y conectividad del paisaje sobre esta y otras especies de fauna silvestre.

Keywords: generalized linear models; management; multivariate analysis; Odocoileus virginianus.

(c) 2017 Asociación Mexicana de Mastozoología, www.mastozoologiamexicana.org

\section{Introduction}

The white-tailed deer Odocoileus virginianus is the most important game species in Mexico (Ortega-Santos et al. 2011). This deer species can be found in different habitats including dry tropical forests, temperate forests, and xeric shrubland, among others (Gallina et al. 2010). In addition, this species persists in farming and ranching areas interspersed with patches of the original habitat (Mandujano et al. 2014). However, white-tailed deer populations are affected by poaching, irrational use, habitat disruption, competition for resources with domestic livestock, and incidence of parasites (Ortega-Santos et al. 2011). A proper utilization of this species requires estimating population den- sity and its relationship with different features of the habitat, vegetation and landscape, among others (Ortiz-Martinez et al. 2005; López-Tellez et al. 2007; Medina-Torres et al. 2008; Mandujano et al. 2013; Ramos-Robles et al. 2013; BarreraSalazar et al. 2015; García-Marmolejo et al. 2015). Unlike other regions of the country - for example the northeast (Villarreal 1999), La Michilía in Durango (Galindo-Leal and Weber 1998), the Mixteca Poblana (Villarreal-Espino 2006), and various regions of the state of Oaxaca (Mandujano 2016) - management of the white-tailed deer is not an extensive practice in the state of Veracruz; hence, a larger number of studies are required for its populations (Mandujano 2011). Investigations conducted on this species 
in Veracruz include topics such as the distribution of deer, habitat quality and management in Management Units for Wildlife Conservation and Sustainable Use (UMAs) (Bello and Mandujano 1994; Gallina et al. 2007; Delfín-Alfonso et al. 2009; Bolívar-Cime and Gallina 2013, Serna-Lagunes et al. 2013a, $\underline{\mathrm{b}}$; Contreras-Verteramo et al. 2014; Mandujano and López-Tello 2015).

The objective of this work was to estimate and compare the population density of the white-tailed deer in five locations and its relationship with variables in the different types of vegetation in a landscape of the municipality of Tantoyuca, northern Veracruz. Ethnic groups such as the Huasteco and the Nahuatl coexist in this mountainous area of the Huasteca Alta Veracruzana (Reyes 2009); $77 \%$ of these human populations have been classified as living in poverty, under marginality conditions and under a high social gap (SEFIPLAN 2016). The main productive activities in the region are temporal agriculture and livestock raising. Similar to many regions of the state, the white-tailed deer is subjected to uncontrolled hunting. In some cases, local inhabitants complain that the deer damages crops, although there are also communities that protect and hunt it for their own consumption. However, to date there are no UMAs to exploit it legally. Consequently, the present work also aims to issue some recommendations for the protection and potential management of the white-tailed deer and its habitat in this region.

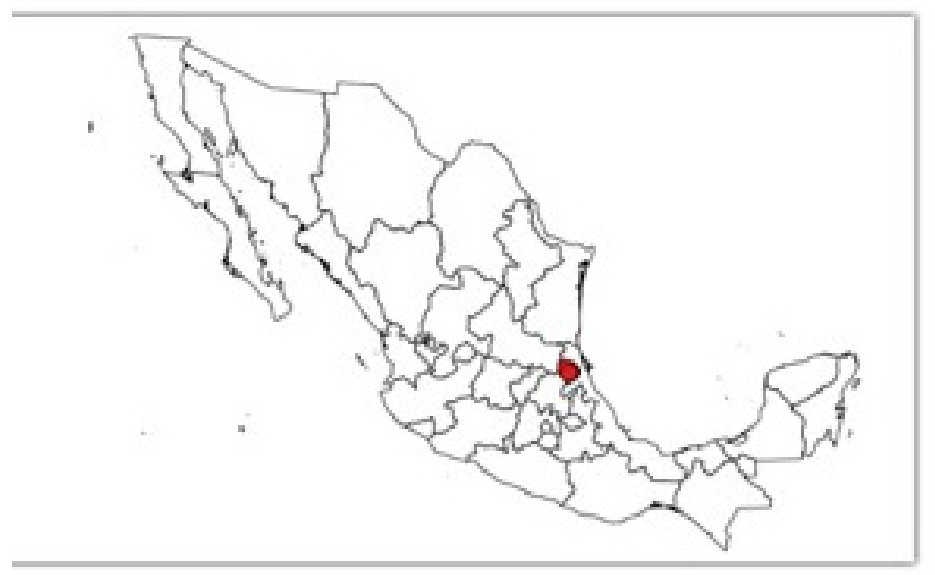

\section{- $\underline{\text { Sites }}$}

\section{$\sim$ Vegetation types}

D $\square$ Oak forest

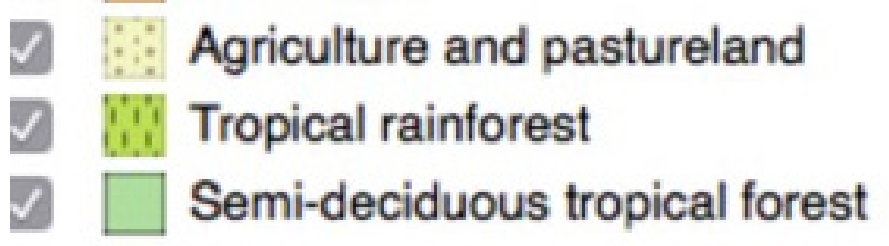

\section{Materials and Methods}

Study area. The study was conducted in five locations (Chiquero, Pensador Mexicano, Porvenir, Monte Grande and Corralillo) located in the municipality of Tantoyuca in the northern portion of the state of Veracruz (Figure 1a). The municipality is located at $21^{\circ} 06^{\prime}$ to $21^{\circ} 40^{\prime} \mathrm{N}$ and $-97^{\circ} 59^{\prime}$ to $-98^{\circ} 24^{\prime} \mathrm{E}$ at an altitudinal range of 10 to $300 \mathrm{~m}$. Climate is warm subhumid with a mean annual precipitation of 1200 $\mathrm{mm}$ and a mean annual temperature of $24{ }^{\circ} \mathrm{C}$ (INEGI 2009). The landscape lies within the Calabozo river basin, a tributary of Panuco river, and in small streams emptying into Topila estuary (INEGI 2009). The municipality has an area of $1,303 \mathrm{~km}^{2}$ and comprises 511 rural and one urban localities. The original representative vegetation in this region was sub-evergreen forest with patches of high tropical forest (Rzedowski 1978). Current land use in the municipality includes agriculture (13\%), pastureland (57\%), secondary vegetation ( $28 \%)$ and urban area $(<1 \%)$. Local economic activities include agriculture, livestock raising (cattle, pigs and sheep) and poultry (INEGI 2009). Consequently, the landscape is a mosaic of different vegetation types with varying degrees of disturbance, alternating with small patches of the original forest, pastureland and cultivated areas (Figure 1b).

Field sampling. The five study localities were selected based on ease of field sampling and the interest of the local community in caring for and making good use of deer

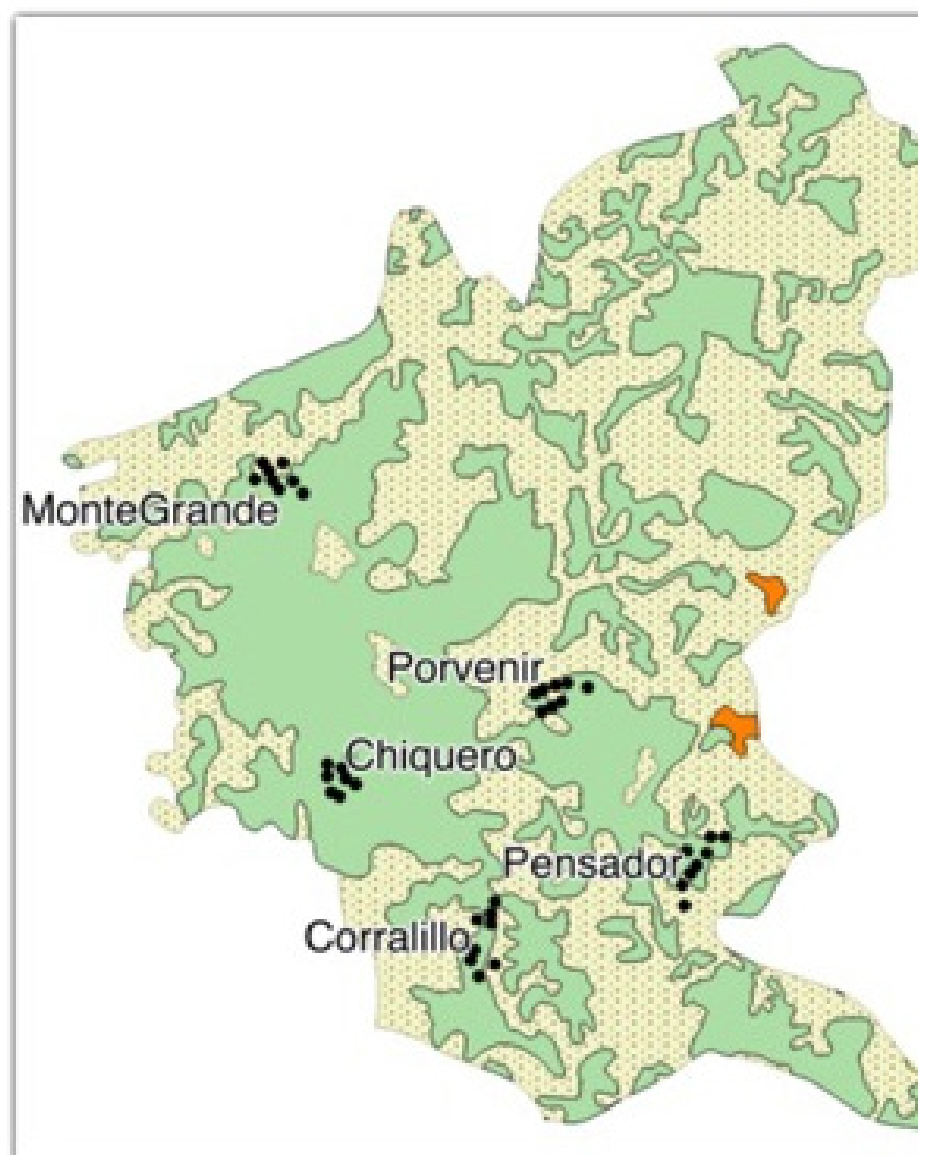

Figure 1. (a) Geographic location and dominant vegetation types according to INEGI (20005) in the region of study, municipality of Tantoyuca, northern state of Veracruz. (b) Landscape heterogeneity. 
within their premises. Vegetation was characterized using the same protocol as in previous studies (Mandujano et al. 2013; Ramos-Robles et al. 2013; Barrera-Salazar et al. 2015). Basically, eight 500-m transects were set in each location, with 11 sampling points separated by $50 \mathrm{~m}$ between them in each location, for a total of 440 points. Vegetation was sampled using the point quadrat method, also used in previous studies on deer. The variables studied were composition of tree species, richness (N0), Shannon diversity $(H)$, Hill's diversity (N1), evenness (E1), density (Arb_den), height (Arb_alt) and basal area (Arb_ab) of the tree stratum; understory species richness $(\mathrm{S})$; and protection cover at $0-50 \mathrm{~cm}$ (cob_50) and 51-100 cm (cob_100). N0, H, N1 and E1 were calculated using the package $R$ (Bocard et al. 2010). Samplings were carried out between April and June 2014.

For deer pellet counts, 40 strip transects measuring $500 \times 2 \mathrm{~m}$ sere set, with a minimum separation of $500 \mathrm{~m}$ between them. This distance attempted to prevent that the same animal leave traces in different transects; however, this might not be true in all cases (Mandujano 2014a). Each transect was divided into 10 sampling plots measuring $50 \mathrm{x}$ $2 \mathrm{~m}$ for counting and collecting all deer pellet groups, taking care not to miss feces within the transect, nor include those observed outside the strip, to avoid any bias. Samplings were conducted during the dry season from April to June 2014. All transects were sampled by the same person assisted by local inhabitants, in order to reduce any observational bias during sampling. Location data were collected using GPS, and were subsequently imported to the program QGIS 2.4 (http://qgis.org/es/site/) for its spatial projection.

Classification of vegetation. Each transect was classified according to the dominant vegetation type in INEGI's National Forest Inventory map (2005) (Figure 1a). However, considering the heterogeneity of the landscape, a single transect frequently covered one or more vegetation types; in these cases, transects were classified according to the dominant vegetation. In addition to the classification of INEGI (2005), in this study we classified the 40 transects according to their similarity in the composition of tree species. To this end, hierarchical clustering methods were used for species abundance data through multivariate clustering analysis. The original matrix was 40 transects by 101 species. However, in order to facilitate the data analysis and interpretation, 57 species with less than 15 individuals were removed. The analysis used the procedures described in Bocard et al. (2010) and the ade4 gclus, vegan, and cluster packages in R. The matrix of Euclidean distances between taxonomic groups was calculated using the hclust function. The classification methods used were the unweighted-pairgroup method of analysis (UPGMA) and Ward's minimum variance. The results of hierarchical clustering were interpreted and compared using some indices and plots provided by these packages. Finally, the species assigned to groups or "clusters" were examined with the vegemite function of the vegan package (Bocard et al. 2010).

\section{a)}

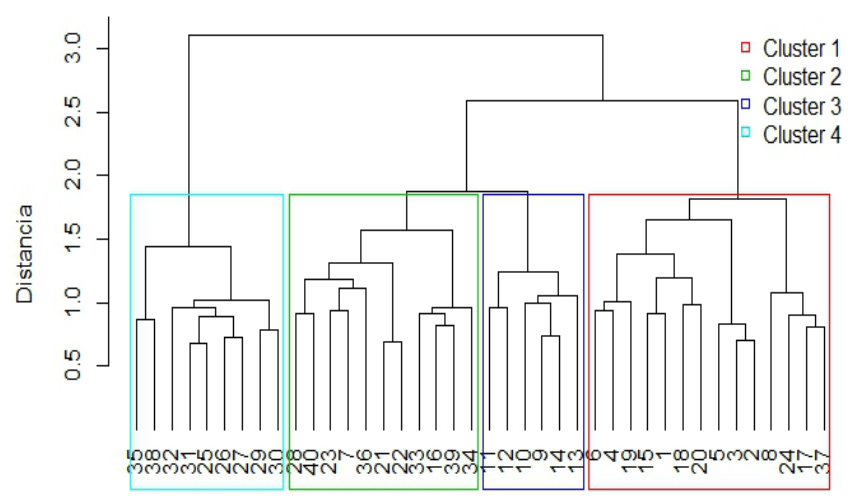

Transectos por grupo

\section{b)}

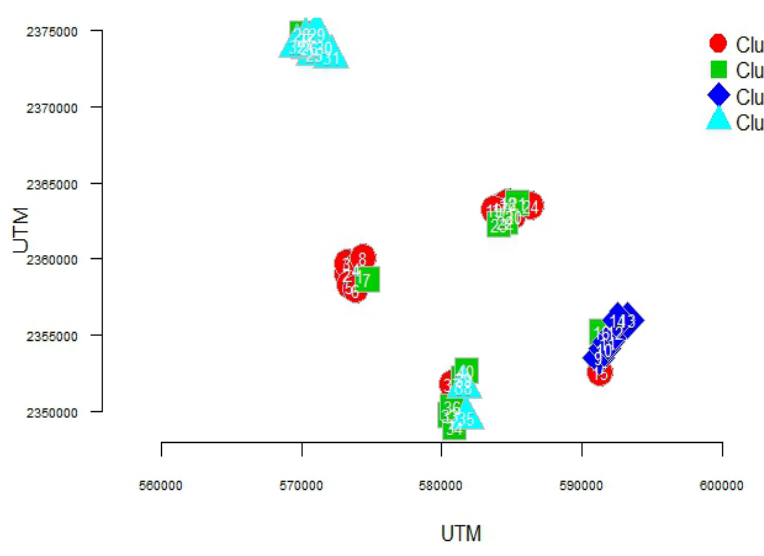

c)

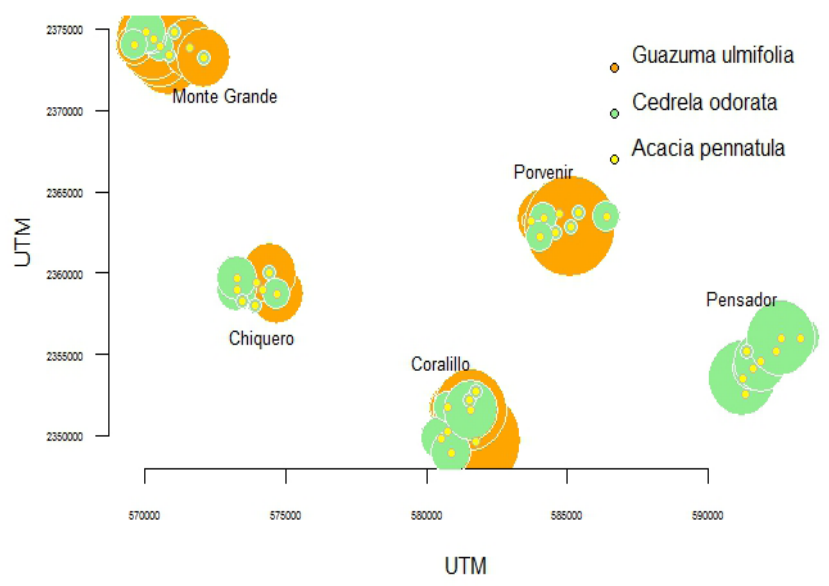

Figure 2. Classification of transects using the Ward's clustering method (a). Spatial distribution of the 40 transects classified into four groups (b). The colors in both figures match. Spatial distribution of the three most abundant tree species in the transects in each of the five study locations (C). Circle size is proportional to tree abundance. 
Once the classification of transects in each group was completed, the vegetation variables (NO, H, E1, Arb_den, Arb_alt, Arb_ab, S, cob_50 and cob_100) were tested for statistical differences using one-way ANOVAs. Previously, the Shapiro test was run to confirm the normality of the residuals, and Bartlett's test to determine the homogeneity of variances. In case of significance in the analysis of variance, Tukey's HSD test was used a posteriori for determining differences between groups (Crawley 2013).

Relationship between density and vegetation. Population density was estimated with the program PELLET version 2.0 for Excel (Mandujano 2014b). The equation for estimating population density was: $D=\left(D_{p g} * N p\right) /(T d f * T d e p)$, where: $D=$ deer population density (number of individuals per $\mathrm{km}^{2}$ ), $\mathrm{D}_{\mathrm{pg}}$ $=$ average density of pellet groups per transect, $\mathrm{N}_{\mathrm{p}}=$ Number of transects sampled, $\mathrm{T}_{\mathrm{df}}=$ defecation rate, and $\mathrm{T}_{\text {dep }}^{\mathrm{p}}=$ days of deposition. This procedure uses three defecation rates (13, 19 and 26 pellet groups/ind/day) obtained in several studies, while exposure rate is calculated from the latest rainfall in the study site and the sampling date in each transect. Further details on this procedure are provided in the work of Mandujano $(2014 \mathrm{a}, \underline{\mathrm{b}})$.

Prior to the statistical comparison of deer density, preliminary analyses of the data were carried out using the quantil-quantil plot function in $\mathrm{R}$, where theoretical and sampling residuals were plotted (Crawley 2013). The influence function was used to detect any observations ("outliers") that might skew to a greater extent the density estimates. Deer density was estimated at four levels: 1) for the whole municipality, by grouping all transects; 2 ) for each of the five locations; 3 ) by vegetation type according to the INEGI classification (INEGI 2005); and 4) by groups or clusters obtained from the multivariate analysis. The Gamma function was used for the first level; this tool is very useful for ecological data with values above zero and kurtosis skewed to the right (Bolker 2008), as is the case of population density. Differences in deer density for the different levels of analysis (subparagraphs 2, 3 and 4 above) were compared using a one-way analysis of variance and tested a posteriori with Tukey's HSD multiple comparison test.

To determine the relationship between deer density and vegetation variables (Arb_den, Arb_alt, Arb_ab, N0, N1, H, E1, S, cob_50, and cob_100), we first examined whether there was a correlation between some of these variables using the $\mathrm{R}$ pairs function. This preliminary analysis allowed the elimination of six of these variables. Subsequently, we analyzed the relationship between variable-dependent density through a generalized linear model. All statistical and graphical analyses were conducted using the statistical program R 3.1.2 (R Development Core Team 2015).

\section{RESULTS}

Classification of vegetation. A total of 1,756 trees of 101 species belonging to 49 botanical families were counted. Four groups or clusters of transects were obtained, which correspond to the locations studied (Figure 2a), as follows: a)

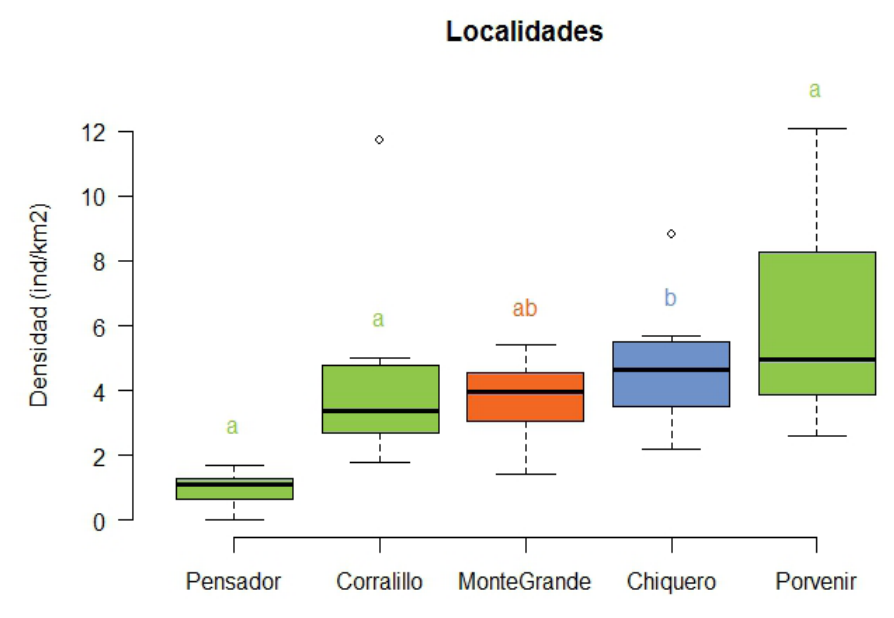

b)

Tipos de vegtacion

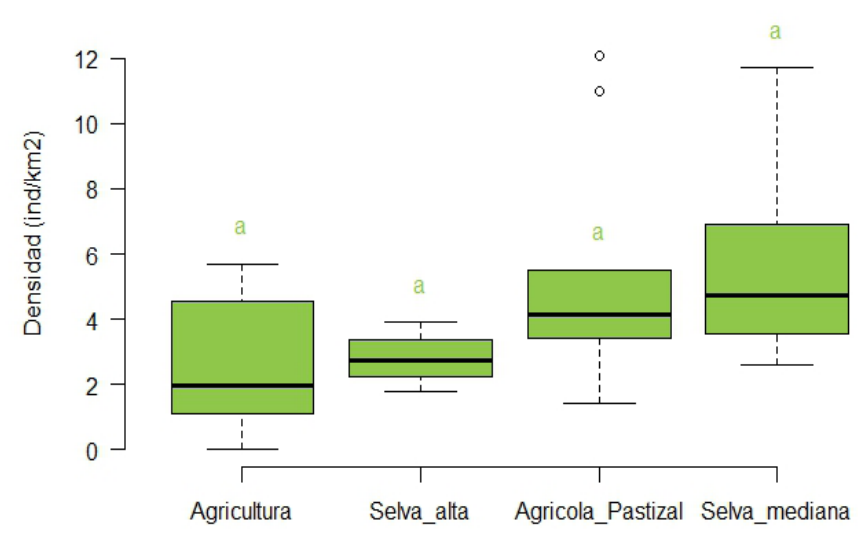

c)

Grupos multivariado

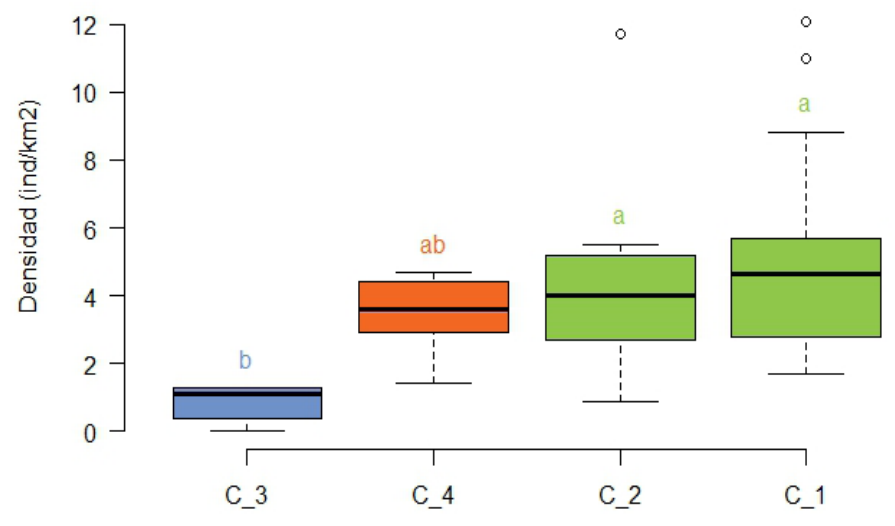

Figure 3. Estimates of the density (ind $/ \mathrm{km}^{2}$ ) of the white-tailed deer in the study localities (a), vegetation types (b), and the groups (clusters) obtained in the multivariate analysis (c). Black lines inside boxes represent the value of the median. Lowercase letters above each bar represent the a-posteriori comparisons of the Tukey HSD test; same letters indicate non-different estimates. 
group 1, Chiquero; group 2, Corralillo; group 3, Pensador; and group 4, Monte Grande; the Porvenir locality can be classified into groups 1 and 2 (Figure 2b). The similarity between transects of the same group and the difference between groups can be explained by the difference in the abundance of tree species. Group 1 was represented mainly by Acacia pennatula, Pithecellobium lanceolatum and Aldama dentatathe; group 2 was the most heterogeneous one, represented mainly by Malvaviscus arboreus, Tabebuia rosea, Croton glabellus and Croton sp; group 3 is represented mainly by Cedrela odorata. According to the degree of similarity, group 4 showed the lowest similarity relative to all other groups, and is represented by Guazuma ulmifolia, Croton glabellus and Ehretia tinifolia (Figure 2c).

With regard to the comparison of vegetation types, those corresponding to agriculture and secondary medium forest vegetation were different vs. agriculture-pastureland and secondary vegetation with high-forest elements. The significant variables were tree height $(F=3.37, P=0.029)$, basal area $(\mathrm{F}=4.88, P=0.006)$, tree richness $(\mathrm{F}=5.01, P=$ $0.005)$, understory richness $(F=4.88, P=0.006)$ and diversity of the tree stratum $(\mathrm{F}=4.56, P=0.008)$. On the other hand, at the level of groups and localities, group 3 corresponding to Pensador had the lowest density $(F=5.91, P=$ $0.002)$, height $(F=6.86, P=0.001)$, basal area $(F=22.58, P$ $=0.002)$ and cover at $100 \mathrm{~cm}(\mathrm{~F}=6.05, P=0.001)$. Group 1 (Chiquero and Porvenir), group 2 (Corralillo and Porvenir) and group 4 (Monte Grande) did not differ with each other.

Relationship between deer density and vegetation. There were a total of 421 pellet groups in 39 of the 40 transects sampled in the five study localities. Average density for the entire region was estimated at $4.0 \pm 2.8 \mathrm{ind} / \mathrm{km}^{2}$. Density varied between localities, being statistically lower in Pensa-
Table 1. Estimates of the coefficients of each variable of generalized linear models (GLM). Abbreviations: Arb_den = tree density, Arb_ab = basal area, N0 = species richness of the tree stratum, Cob_100 = understory cover at $100 \mathrm{~cm}$ height.

\begin{tabular}{|c|c|c|c|c|}
\hline Variable & Exp(coefficient) & $\operatorname{Exp}(S E)$ & Z Value & PValue \\
\hline \multicolumn{5}{|c|}{ Model 1: glm(Density Arb_den + Arb_ab + N0 +Cob_100) } \\
\hline Intercept & 1.224 & 2.30 & 0.243 & 0.81 \\
\hline Arb_den & -0.991 & 1.01 & -0.862 & 0.39 \\
\hline Arb_ab & -0.998 & 1.001 & -2.556 & $0.01 *$ \\
\hline No & -0.978 & 1.02 & -1.219 & 0.22 \\
\hline Cob_100 & 1.025 & 1.01 & 2.968 & $0.003^{* *}$ \\
\hline \multicolumn{5}{|c|}{$\begin{array}{l}\text { Null deviance: } 73.42 \text { on } 39 \mathrm{gl} \\
\text { Residual deviance: } 50.59 \text { on } 35 \mathrm{gl}\end{array}$} \\
\hline \multicolumn{5}{|c|}{ Model 2: glm(Density Arb_ab +Cob_100) } \\
\hline Intercept & 0.730 & 2.12 & 0.418 & 0.68 \\
\hline Arb_ab & -0.998 & 1.01 & -2.447 & $0.014^{*}$ \\
\hline Cob_100 & 1.024 & 1.01 & -2.941 & $0.003^{* *}$ \\
\hline $\begin{array}{l}\text { Null deviance } \\
\text { Residual dev }\end{array}$ & $\begin{array}{l}2 \text { on } 39 \mathrm{gl} \\
50.59 \text { on } 35 \mathrm{gl}\end{array}$ & & & \\
\hline
\end{tabular}

dor (Figure 3a; $F=5.1$, d .f. $=4,35, P=0.002$ ). With regard to vegetation types, a trend was observed toward a lower deer density in agricultural areas and a higher density in forest patches (Figure 3b; $F=3.39$, d. f. $=3,36, P=0.03$ ). With regard to groups based on similarity in composition, the statistically lowest density was estimated for group 3 (Figure 3c; $F=4.85$, d. f. $=3,36, P=0,006$ ).

Of the ten vegetation variables originally calculated, six were eliminated for displaying a high colinearity. The coefficients of the first GLM suggest that tree density and Hill's diversity index do not make a significant contribution (Table 3). The second model indicates that a higher percent understory cover and a lower basal area of the tree stratum predict a higher white-tailed deer density in the study area (Figure 4).

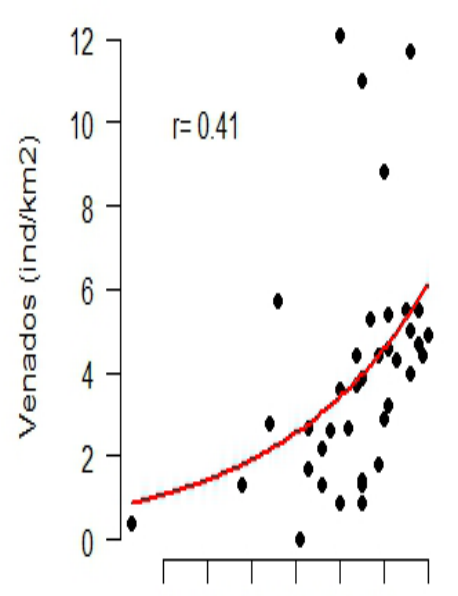

$40506070 \quad 8090$

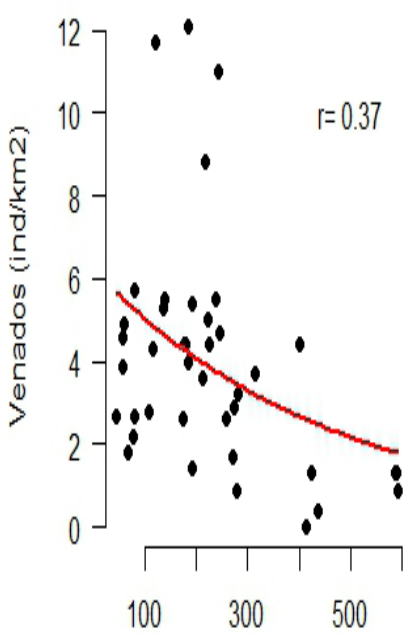

Area basal

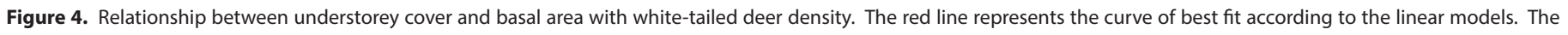
correlation coefficient $(r)$ is shown. 


\section{DISCUSSION}

The white-tailed deer was recorded in $98 \%$ of the transects sampled, with an estimated mean density of 4 ind/ $\mathrm{km}^{2}$ for the whole area. This density lies within the range reported for other regions of the state of Veracruz, i. e. 1 to $8 \mathrm{ind} / \mathrm{km}^{2}$ (Contreras-Verteramo et al. 2014; Serna-Lagunes et al. 2013b; Mandujano and López-Tello 2015). Deer density in the landscape studied is relatively similar to the one reported for other regions with secondary vegetation alternating with remnants of medium forest in southeastern Mexico (González-Marín et al. 2008; Bello et al. 2004).

The use of generalized linear models enabled to predict a higher density of white-tailed deer in areas where the protection cover is high and the tree stratum is dominated by species with relatively low basal areas, i. e. thin trees such as Acacia spp., Mimosa spp., Cedrela odorata and Guazuma ulmifolia. Several of these genera and species are consumed by deer elsewhere (Villarreal-Espino 2006; Vázquez et al. 2015). The five study localities were classified according to the composition and abundance of the main tree species. In particular, the highest estimated densities corresponded to Monte Grande, Porvenir, Chiquero and Corralillo, with a more diverse and dense vegetation composition and structure. In the landscape studied, the highest cover was found in patches with secondary vegetation resulting from slash-and-burn agriculture, which allows the regeneration of the tree vegetation after two or three years of use for agriculture (Reyes 2009). In contrast, the lowest density was estimated for Pensador, a locality characterized by less favorable conditions for the white-tailed deer due to increased livestock raising and greater poaching pressure according to some persons. Other studies in forests have also documented that deer densities are higher where the vegetation provides this and other deer species with food and a dense cover to meet their needs for protection against harsh temperatures and predators (Ortiz-Martinez et al. 2005; Medina-Torres et al. 2008; Flores-Armillas et al. 2013).

The white-tailed deer is exploited by local inhabitants, but as of today the number of animals hunted in the region has not been quantified, nor whether the rate exceeds a potential sustainable use. According to the experience in central Veracruz, the white-tailed deer could be managed under the diversified livestock scheme to contribute to conservation and use, incorporating other productive activities such as ecotourism, hunting tourism and scientific tourism, as an alternative to generate income for UMA owners, contributing to the improvement and conservation of ecosystems at the regional level (Serna-Lagunes et al. 2013b). According to Mandujano (2010), the sustainable development model in extensive UMAs in tropical regions is feasible only if these incorporate areas of several thousands of hectares at the landscape level (Mandujano and González-Zamora 2009). In this sense, a recent experience in central Veracruz suggests that the management of this deer species is not sustainable in UMAs of less than 3000 hectares (Mandujano and López-Tello 2015). Another relevant aspect is that intense and constant work with human communities is required in order to incorporate them to the management of this animal resource (Lopez-Tellez et al. 2016). In addition, considering that the study region is still home to human communities of different ethnic origin, conducting intense work from an ethno-zoological perspective is suggested (Mandujano and Rico-Gray 1991; Naranjo et al. 2004).

Similar to what has happened in other regions of the state of Veracruz (Landeros-Sánchez et al. 2011), the landscape studied is currently made up of a complex mosaic of temporary and permanent agriculture, cultivated pastureland for bovine cattle raising, and remnants of secondary vegetation with the tree stratum of medium semi-deciduous and high tropical forest. In this sense, and considering that sampling was performed only during the dry season of 2014, a very interesting aspect to address in future studies refers to the structural complexity of landscape and the presence of relatively large patches of tree vegetation, which would benefit the white-tailed deer and other wildlife species, similar to what has been documented for other regions of southeastern Mexico (García-Marmolejo et al. 2015; Contreras-Moreno et al. 2016).

\section{ACKNOWLEDGMENTS}

The first author received a CONACYT scholarship for an undergraduate thesis (No. 21639) as part of the research project No. CB-2009-01-130702. We are grateful to A. Mora, V. Vázquez, C. A. Perez Camacho, A. Perez and D. Ramos for their assistance in field work, and also to G. N. Nava, T. Perez-Perez, E. Lopez-Tello, and R. Rodriguez for their support in various logistical aspects. The Network of Biology and Vertebrate Conservation at Instituto de Ecología A.C. in Xalapa provided support for the conduct of this work. M. E. Sánchez-Salazar translated the manuscript into English.

\section{LITERATURE CITED}

Barrera-Salazar, A., S. Mandujano, O. A. Villarreal Espino-Barros, And D. JIMÉnEZ-GARCíA. 2015. Classification of vegetation types in the habitat of white-tailed deer in a location of the TehuacánCuicatlán Biosphere Reserve, Mexico. Tropical Conservation Science 8:547-563.

Bello, J., and S. Mandujano. 1994. Estado actual de las poblaciones de venado cola blanca y temazate en los "Tluxtlas", Veracruz. Memorias del V Simposio Sobre Venados en Tamaulipas. Universidad Nacional Autónoma de México. Ciudad de México, México.

Bello, J., C. Guzmán, And J. ZúÑIGA. 2004. Aspectos ecológicos del venado cola blanca y Temazate en la región de Sierra del estado de Tabasco. Memorias IX Simposio Sobre Venados en México. Facultad de Medicina Veterinaria y Zootecnia de la Universidad Nacional Autónoma de México. Ciudad de México, México.

Bocard, D., F. Gillet, and P. Legendre. 2010. Numerical ecology with R. Springer, New York, U. S. A.

Bolívar-Cimé, B., and S. Gallina. 2013. An optimal habitat model 
for the white-tailed deer (Odocoileus virginianus) in central Veracruz, Mexico. Animal Production Science 52:707-713.

Bolker, B. M. 2008. Ecological models and data in R. Princeton University Press. Princeton, U. S. A.

Contreras-Moreno, F. M., K. Cruz-Félix, J. Bello-Gutiérrez, and M. Gabriel HIDALGO-MiharT. 2016. Variables del paisaje que determinan la presencia de los venados temazates (Mazama sp.) en el oeste del estado de Campeche, México. Therya 7:3-19.

Contreras-Verteramo, C., M. A. Arenas, and A. Pérez. 2014. Manejo de venado cola blanca en la zona Huasteca. Memorias XIV Simposio sobre Venados de México. Facultad de Medicina Veterinaria y Zootecnia, UNAM. Mérida, México.

Crawley, M. J. 2013. The R Book. John Wiley \& Sons. Chinchester, United Kindom

Delfín-Alfonso, C., S. Gallina, and C. A. López-González. 2009. Evaluación del hábitat del venado cola blanca utilizando modelos espaciales y sus implicaciones para el manejo en el centro de Veracruz, México. Tropical Conservation Science 2:215-228.

Flores-Armillas, V. H., F. Botello, V. Sánchez-Cordero, R. GarcíaBarrios, F. Jaramillo, and S. Gallina. 2013. Caracterización del hábitat del venado cola blanca (Odocoileus virginianus mexicanus) en los bosques templados del Corredor Biológico Chichinautzin y modelación de su hábitat potencial en Eje Transvolcánico Mexicano. Therya 4:377-393.

Galindo-Leal, C., And M. Weber. 1998. El venado de la Sierra Madre Occidental. Ecología, Manejo y Conservación. Ediciones Culturales S.A. de C.V., Comisión Nacional para el Conocimiento y Uso de la Biodiversidad, Ciudad de México, México.

GallinA, S. 2014. Características y evaluación del hábitat del venado. Pp. 45-71, in Monitoreo y manejo del venado cola blanca: conceptos y métodos (Gallina, S., S. Mandujano, and O. A. Villarreal Espino-Barros, eds). Instituto de Ecología A. C. and Benemérita Universidad Autónoma de Pueba. Xalapa, México.

Gallina, S., C. A. Delfín-Alfonso, S. Mandujano, L. A. Escobedo Morales, and R. G. González-Trapaga. 2007. Situación actual del venado cola blanca en la zona centro del estado de Veracruz, México. Deer Specialist Group Newsletter 2:29-33.

Gallina, S., S. Mandujano, J. Bello, H. López-Fernández, and M. Weber. 2010. White-tailed deer Odocoileus virginianus (Zimmermann, 1780). Pp.101-118, in Neotropical Cervidology: Biology and medicine of Latin American deer (Duarte, J. M. B., and S. González, eds.). Jaboticabal, Brazil: Funep and Gland, Switzerland, IUCN.

García-Marmolejo, G., L. Chapa-Vargas, M. Webera, and E. HuberSANNWALD. 2015. Landscape composition influences abundance patterns and habitat use of three ungulate species in fragmented secondary deciduous tropical forests, Mexico. Global Ecology and Conservation 3:744-755.

González-Marín, R. M., S. Gallina, S. Mandujano, and M. Weber. 2008. Densidad y distribución de ungulados silvestres en la Reserva Ecológica El Edén, Quintana Roo, México. Acta Zoológica Mexicana (n. s.) 24:73-93.

INEGI (Instituto Nacional de Estadística, Geografía e Informática). 2005. Carta de uso de suelo y vegetación de Tantoyuca, Veracruz, en escala 1:250 000 serie V. URL http:// www.inegi.org.mx

INEGI (Instituto Nacional de Estadística, Geografía e Informática). 2009. Prontuario de información geográfica municipal de los Estados Unidos Mexicanos. Tantoyuca, Veracruz. http://www3.inegi.org.mx/sistemas/mexicocifras/ datos-geograficos/30/30155.pdf

Landeros-Sánchez, C., C. J. Moreno-Seceña, L. N. Gavrilov, and O. B. Egorova. 2011. Impacto de la agricultura sobre la biodiversidad. Pp. 477-491, in La biodiversidad en Veracruz: estudio de Estado (Cruz Angón, A., ed.). Comisión Nacional para el Conocimiento de la Biodiversidad, Gobierno del Estado de Veracruz, Universidad Veracruzana, Instituto de Ecología, A. C. Ciudad de México, México.

López-Téllez, M. C., A. Barrera-Salazar, B. Ramírez-Vera, S. ChávezHerrera, S. Mandujano, and J. M. Salazar-Torres. 2016. Primera experiencia de la cacería deportiva del venado cola blanca en UMA extensiva en la RBTC. Pp. 161-176, in Venado cola blanca en Oaxaca: potencial, conservación, manejo y monitoreo (Mandujano, S., ed.). Instituto de Ecología, A. C. and Comisión Nacional para el Conocimiento de la Biodiversidad. Xalapa, México.

López-Téllez, M. C., S. Mandujano, and G. Yáñez. 2007. Densidad poblacional y características del hábitat del venado cola blanca (Odocoileus virginianus mexicanus) en un bosque tropical seco de Puebla. Acta Zoológica Mexicana (n. s.) 23:1-6.

Mandujano, S. 2010. Potencial del bosque tropical seco para producción de venado cola blanca (Odocoileus virginianus) en México. Pp. 101-130, in Conservación y manejo de fauna cinegética de México Vol. II (O. A. Villarreal Espino Barros, J. E. Hernández, J. C. Camacho, and F. J. Franco, eds.). Benemérita Universidad Autónoma de Puebla. Puebla, México.

Mandujano, S. 2011. Bibliografía Estudios de Venados en México. Colección Manejo de Fauna Silvestre No. 2, Instituto Literario de Veracruz S. C. Xalapa, México.

MANDUJANo, S. 2014a. Manual para estimar la densidad venados en UMAs y ANPs empleando PELLET. Instituto de Ecología A. C. Xalapa, México.

Mandujano, S. 2014b. PELLET: An Excel ${ }^{\circledR}$-based procedure for estimating deer population density using the pellet-group counting method. Tropical Conservation Science 7:308-320.

Mandujano, S. (editor). 2016. Venado Cola Blanca en Oaxaca: Potencial, Conservación, Manejo y Monitoreo. Comisión Nacional para el Conocimiento de la Biodiversidad (CONABIO) e Instituto de Ecología A. C. Xalapa, México.

Mandujano, S., and V. Rico-Gray. 1991. Hunting, use, and knowledge of the biology of the white-tailed deer, Odocoileus virginianus (Hays), by the Maya of central Yucatan, Mexico. Journal of Ethnobiology 11:175-183.

Mandujano, S., and A. González-Zamora. 2009. Evaluation of natural conservation areas and wild life management units to support minimum viable populations of white-tailed deer in Mexico. Tropical Conservation Science 2:237-250.

Mandujano, S., And E. López-Tello. 2015. Estudios y talleres para el monitoreo poblacional y de hábitat del venado cola blanca (Odocoileus virginianus veraecrucis) en UMAs extensivas en los municipios de Actopan/Alto Lucero, Veracruz. Informe Técnico Final, Proyecto Estratégico No. 20035-30918, Instituto de Ecología A. C. Xalapa, México.

Mandujano, S., S. Gallina, and J. Alfonso Ortega. 2014. Venado 
cola blanca en México. Pp. 523-542, in Ecología y Manejo de Fauna Silvestre en México (Valdez, R., and J. Alfonso-Ortega, eds.). Biblioteca Básica de Agricultura, Editorial del Colegio de Postgraduados, Colegio de Postgraduados, Universidad Autónoma Chapingo. Guadalajara, Jalisco, México.

Mandujano, S., C. Yañez-Arenas, A. González-Zamora, and A. PérezARteAgA. 2013. Habitat-population density relationship for the white-tailed deer Odocoileus virginianus during the dry season in a Pacific Mexican tropical dry forest. Mammalia 77:381-389.6-6.

Medina-Torres, S., E. García, M. Márquez, H. Vaquera, A. Romero, and M. MARTíneZ. 2008. Factores que influyen en el uso del hábitat por el venado cola blanca (Odocoileus virginianus couesi) en la sierra del Laurel, Aguascalientes, México. Acta Zoológica Mexicana (n. s.) 24:191-212.

Naranjo, E. J., M. M. Guerra, R. E. Bodmer, and J. E. Bolaños. 2004. Subsistence hunting by three ethnic groups of the Lacandon forest, México. Journal of Ethnobiology 24:233-253.

Ortega-Santos, A., S. Mandujano, J. Villarreal, M. I. Dimari, H. LópezArévalo, M. Correa, and M. Molina. 2011. White-tailed deer in Latin America. Pp. 565-597, in Biology and Management of White-Tailed Deer (Hewitt, D., ed.). CRC Press, Taylor \& Francis Group. Boca Raton, U.S. A.

Ortiz-Martínez, T., S. Gallina, M. Briones-Salas, and G. González-Pérez. 2005. Densidad poblacional y caracterización del hábitat del venado cola blanca (Odocoileus virginianus oaxacensis, Goldman y Kellogg, 1940) en un bosque templado de la sierra norte de Oaxaca, México. Acta Zoológica Mexicana (n. s.) 21:65-78.

R Development Core Team. 2015. R: A language and environment for statistical computing. $\mathrm{R}$ Foundation for Statistical Computing. Vienna, Austria. URL http://www.R-project.org.

Ramos-Robles, M. I., S. Gallina, and S. Mandujano. 2013. Habitat and human factors associated with white-tailed deer density in the tropical dry forest of Tehuacán-Cuicatlán Biosphere Reserve, Mexico. Tropical Conservation Science 6:70-86.

REYES, A. 2009. Manejo del ixtle para la manufactura de productos útiles en la comunidad "Teenek" de Xilozuchil municipio de Tantoyuca, Veracruz. Tesis Licenciatura, facultad de Biología, Universidad Veracruzana. Xalapa, Ver., México

Rzedowskı, J. 1978. La vegetación de México. Editorial Limusa. Ciudad de México, México.

SEFIPLAN (Secretaria de Finanzas y Planeación del Estado de Veracruz). 2016. Sistema de información municipal. Cuadernillos municipales Tantoyuca.

Serna-Lagunes R., C. A. Olguín, J. A. Pérez, C. G. García, I. Casas, and J. SALAZAR. 2013a. Venado veracruzano: (Odocoileus virginianus veraecrucis Goldman \& Kellogg, 1940): Una opción para la ganadería diversificada y la conservación de ecosistemas. Agroproductividad 6:58-64.

Serna-lagunes R., V. Vega, A. Olguín, and J. Salazar. $2013 \mathrm{~b}$. Densidad de Odocoileus virginianus veraecrucis, mediante conteos directos e indirectos, en la UMA Los Amigos, Catemaco, Veracruz. Memorias XIV Simposio sobre Venados de México. Facultad de Medicina Veterinaria y Zootecnia, UNAM. Mérida, México.

Vasquez, Y., L. Tarango, E. López-Pérez, J. Herrera, G. Mendoza, and S. Mandujano. 2015. Variation in the diet composition of the white-tailed deer (Odocoileus virginianus) in the Tehuacán-
Cuicatlán Biosphere Reserve. Revista Chapingo Serie Ciencias Forestales y del Ambiente 22:57-68.

VillarReAl-Espino, O. 2006. El Venado cola blanca en la mixteca poblana: conceptos y métodos para su conservación y manejo. Fundación Produce Puebla A. C., Puebla, México.

VILLARREAL, J. 1999. Venado cola blanca: manejo y aprovechamiento cinegético. Unión Ganadera Regional de Nuevo León. Monterrey, México.

Associated editor: Rafael Reyna

Submitted: December 13, 2016; Reviewed: January 18, 2017;

Accepted: March 3, 2017; Published on line: April 3, 2017. 